\title{
Thermodynamic Environment During the 2009 Burkina Faso and 2012 Nigeria Flood Disasters: Case Study
}

\author{
R. Ayodeji Balogun, E. Adesanya Adefisan, Z. Debo Adeyewa, and \\ E. Chilekwu Okogbue
}

\section{Contents}

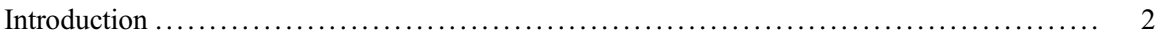

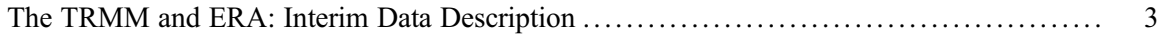

The 2009 Flood in Burkina Faso ............................................. 4

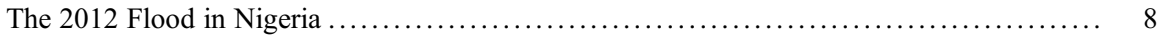

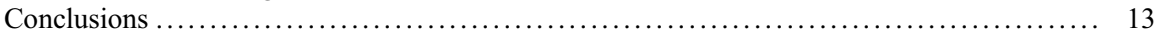

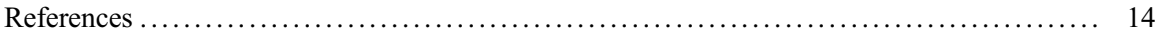

\begin{abstract}
Critical or extreme atmospheric conditions which could result in flood disasters are important output for numerical weather forecast. This research applied thermodynamic variables to investigate the environment of two flood scenarios in West Africa as captured by the Tropical Rainfall Measurement Mission (TRMM) satellite. Results from the two case studies of flood events, in (i) Burkina Faso and (ii) Nigeria savannah, investigated in this research work, indicated that the September 1st 2009 flood, which was as a result of a single volumetric rainfall event of $408,070.60\left((\mathrm{~mm} / \mathrm{h})^{*} \mathrm{~km}^{2}\right)$ with $65 \%$ convective region in Burkina Faso, was initiated by interactions between extremely large lower tropospheric wind shear and cold pool dynamics. The case of the Nigeria savannah floods between July and September, 2012, was triggered by both continuous rainfall and release
\end{abstract}

This chapter was previously published non-open access with exclusive rights reserved by the Publisher. It has been changed retrospectively to open access under a CC BY 4.0 license and the copyright holder is "The Author(s)". For further details, please see the license information at the end of the chapter.

\footnotetext{
R. A. Balogun $(\bowtie) \cdot$ E. A. Adefisan · Z. D. Adeyewa · E. C. Okogbue

Department of Meteorology and Climate Science, Federal University of Technology, Akure,

Nigeria

e-mail: rabalogun@futa.edu.ng; eaadefisan@futa.edu.ng; adeyewa@run.edu.ng;

emokogbue@gmail.com
} 
of water from the lagdo dam in Cameroon, which affected most of the communities in the river Benue axis. The continuous rainfalls were found to be as a result of extremely high convergence of moisture in the river Benue axis at different locations and periods. One of such rainfall events, as captured by TRMM satellite during September 29, 2012 in the Nigeria rainforest zone, indicated that the volumetric rainfall is $351,310.9\left((\mathrm{~mm} / \mathrm{h}) * \mathrm{~km}^{2}\right)$ with only $34 \%$ convective portion. From these results, it can be deduced that a combination of thermodynamic environmental variables, volume rainfall, and other satellite-derived convective parameters could provide important information for flood forecasting.

\section{Keywords}

Flood disaster $\cdot$ Thermodynamic $\cdot$ Environment $\cdot$ Volumetric rainfall $\cdot$ Moisture convergence

\section{Introduction}

Annually, between March and early October, severe precipitation event which are often associated with flash floods events frequently cause severe damage and loss of property and lives in most countries of West Africa (Balogun et al. 2018). This climate change hazard has been linked to pressures from socioeconomic and physical factors (Merem et al. 2019). The magnitude and frequency of climate hazards have generated serious concerns in recent years in Nigeria, since the 2012 flood disaster in the country and most other West African countries in particular. Flood disasters have been a major occurrence that keeps recurring annually, in some parts of Nigeria (Magami et al. 2014). A Post-Disaster Needs Assessment (PDNA), of the 2012 Nigeria flood, was conducted by the Federal Republic of Nigeria (FRN) with technical support from United Nations, European Union, and World Bank. The major aim of the assessment was to reduce the impact of future disasters, since the floods are due to climate change (Nigeria-PDNA 2013).

Burkina Faso, which is surrounded by other West African countries particularly in the south, shared both Savannah and Sahel climates of West Africa. The economy is specifically based on cotton production and gold mining (WB 2017). Most parts of the country, and Ouagadougou which is the capital in particular, were ravaged by a devastating flood event on the 1st of September 2009 (GBF et al. 2010). This was a result of an extreme single-day rainfall amount of $261.3 \mathrm{~mm}$ (Karambiri 2009; GBF et al. 2010; Galvin 2010). GBF et al. 2010 stated that the September 1st 2009 flood event affected 11 out of the 13 regions in Burkina Faso with the majority of the impacts observed to be concentrated in Ouagadougou. According to GBF et al. (2010), the flood event caused at least 46 deaths and about 120,000 victims were affected. The economic impact was estimated at \$201 Million USD in damages, \$33 Million USD in losses, and \$266 Million USD in reconstruction needs (GBF et al. 2010). (Galvin 2010) concluded that the flood event was "heavy," "extreme," "enormous," and "exceptional"; while GBF et al. (2010) concluded that the singleday rainfall represented almost one-third of the total rainfall received annually 
during the monsoon season. The flood event has a return period of more than 10,000 years according to a preliminary statistical analysis by Karambiri (2009).

The 2012 flood disaster in Nigeria was caused by continuous heavy rainfall and the release of water from Lagdo Dam and Lake Nyos in the Cameroon. The water released affected border towns in Nigeria (Ojobor 2014). NIMET (2012) had earlier predicted, in early March during the 2012 rainfall prediction, and cautioned the Nigerian government about the possibility of continuous rainfall, which could result in destructive flooding in most states in Nigeria, with emphasis on the river basin or catchment and coastal communities of Nigeria. NIMET (2012) advised the government of Nigeria to organize public enlightment programs so as to minimize the damages, devastation, and casualties, in terms of lives and properties, most importantly in locations and communities close to rivers, dams, among others. According to Ojobor (2014) and Agada (2015), a huge number of the populations were largely displaced in these communities, due to the 2012 flood event, as predicted by NIMET (2012). The intention was to help Government agencies and the populace to put necessary measures in place to mitigate the effects of flood waters (Ojobor 2014). The second warning came in August 2012 from Cameroun. Akaeze (2012) stated that the Nigerian Government was officially written by the Cameroon government that the Lagdo Dam located in Cameroun has already filled to capacity as a result of continuous rainfall in the location of the dam and if such rainfall amount should continue in the following week, the dam will overflow and will result in recurrent overflow of water (Akaeze 2012). According to Njoku (2013), the Cameroon authority referenced paragraph 3 of article 111, in the 2010 Nigeria-Cameroon Joint Commission regarding the interchange of relevant information as regard the situations around the Lake Nyos and Lagdo Dam, so that the Nigerian Government will take precautionary measures around the flood areas so as to avoid severe loss.

This chapter was contributed in 2019 to investigate the atmospheric environment of the two case studies discussed above. The major limitation was lack of ground observations to validate the satellite data used for this chapter.

\section{The TRMM and ERA: Interim Data Description}

This chapter investigates high resolution $(0.1 \times 0.1)$ TRMM 2 A25 radar-derived rainfall product, alongside derived products of the European Centre for Mediumrange Weather Forecasts (ECMWF) interim reanalysis (ERA-Interim: Simmons et al. 2007; Dee et al. 2011) dataset to investigate the two (2) case studies.

The TRMM orbital data provided date, time, location, and orbit number analyzed in the case studies. The parameters analyzed from the TRMM orbital data are: Infrared (10.8 micron) brightness temperature, near-surface reflectivity, $85 \mathrm{GHz}$ PCT (Polarization Corrected Temperature), and near-surface rain rate. The parameters analyzed from the environment, of ERA-Interim reanalysis dataset are Sounding (skew - T) to further provide information on convective development, convective available potential energy (CAPE), moisture fluxes, lifted index, and vertical wind shear. The environmental parameters were analyzed at 6-hour intervals a day before, during, and a day after the case study event(s). 


\section{The 2009 Flood in Burkina Faso}

The severity of the September 1st 2009 flood made it a focal point of this chapter. The TRMM snapshot of a Mesoscale Convective System (MCS) on September 1, 2009, covering southern and western Burkina Faso, is shown in Fig. 1a-d. The Visible Infrared Scanner (VIRS), in the TRMM satellite, estimated the brightness temperature as low as $178 \mathrm{~K}$ in Fig. 1a. The pattern of the MCS, as shown by the near surface reflectivity (Fig. 1b), 85 GHz Polarization Corrected Temperature (PCT, Fig. 1c), and the near surface rainfall (Fig. 1d), clearly indicated that the system is a line squall which spans several kilometers. The rain rate from the single system is over $130 \mathrm{~mm} / \mathrm{h}$ and the MCS is only $65 \%$ convective (Table 1 ), meaning that the trailing stratiform portion (region) within the system is $35 \%$. The volume of rainfall (volumetric rainfall) from the single system is $408,070.60\left((\mathrm{~mm} / \mathrm{h}) * \mathrm{~km}^{2}\right)$ (Table 1). The total number of flashcount from the single system is 191 as estimated by the Lightning Imaging Sensor (LIS) of the TRMM satellite. The system was captured at exactly 1:04:53 am on the 1st of September 2009 by the TRMM satellite. The vertical cross section, in Fig. 2, shows that the system is about $200 \mathrm{~km}$ horizontally and reaches about $13-14 \mathrm{~km}$ altitude, which is close to the tropopause.

Orbit: 67193, Date: 01_09_2009, Time: 1:4:53 UTC

(a)

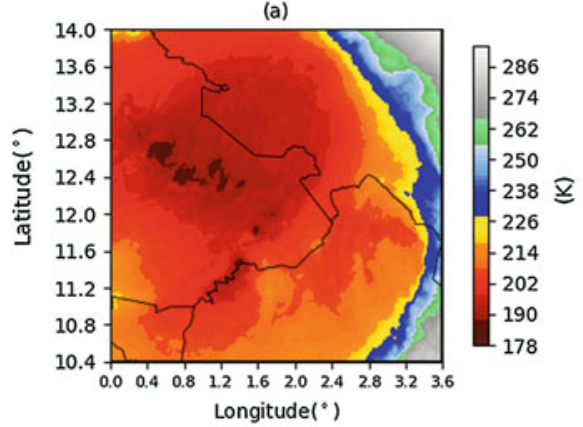

(c)

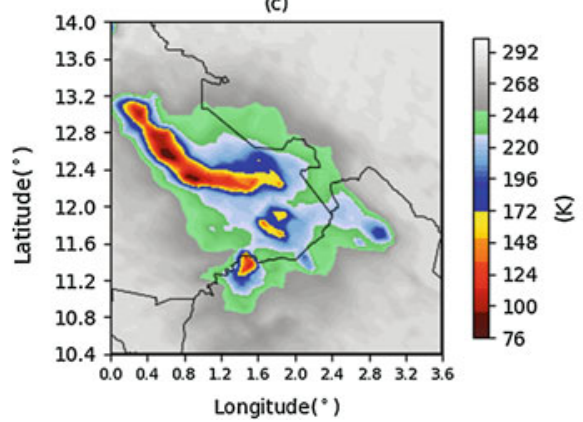

(b)

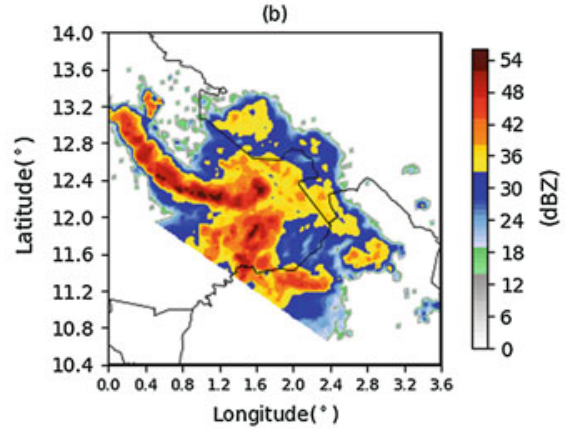

(d)



Fig. 1 Case study of TRMM-observed MCS which occurred on 1st September 2009 in Burkina Faso noted (a) Infrared (10.8 micron) brightness temperature ( $\mathrm{Tb}$ ), (b) PR near surface reflectivity, (c) $85 \mathrm{GHz}$ PCT of MCS, and (d) $2 \mathrm{~A} 25$ near surface rain rate 
Table 1 Summary of some parameters from the observed system during September 1, 2009

\begin{tabular}{l|l|l|l|l|l}
\hline Latitude & Longitude & $\begin{array}{l}\% \\
\text { Convective }\end{array}$ & $\begin{array}{l}\text { Size } \\
\left(\mathrm{Km}^{2}\right)\end{array}$ & $\begin{array}{l}\text { Volrain }((\mathrm{mm} / \mathrm{h}) \\
\left.* \mathrm{~km}^{2}\right)\end{array}$ & $\begin{array}{l}\text { Flashcount } \\
(\#)\end{array}$ \\
\hline 12.16 & 1.64 & 65 & 52116.35 & 408070.6 & 191 \\
\hline
\end{tabular}

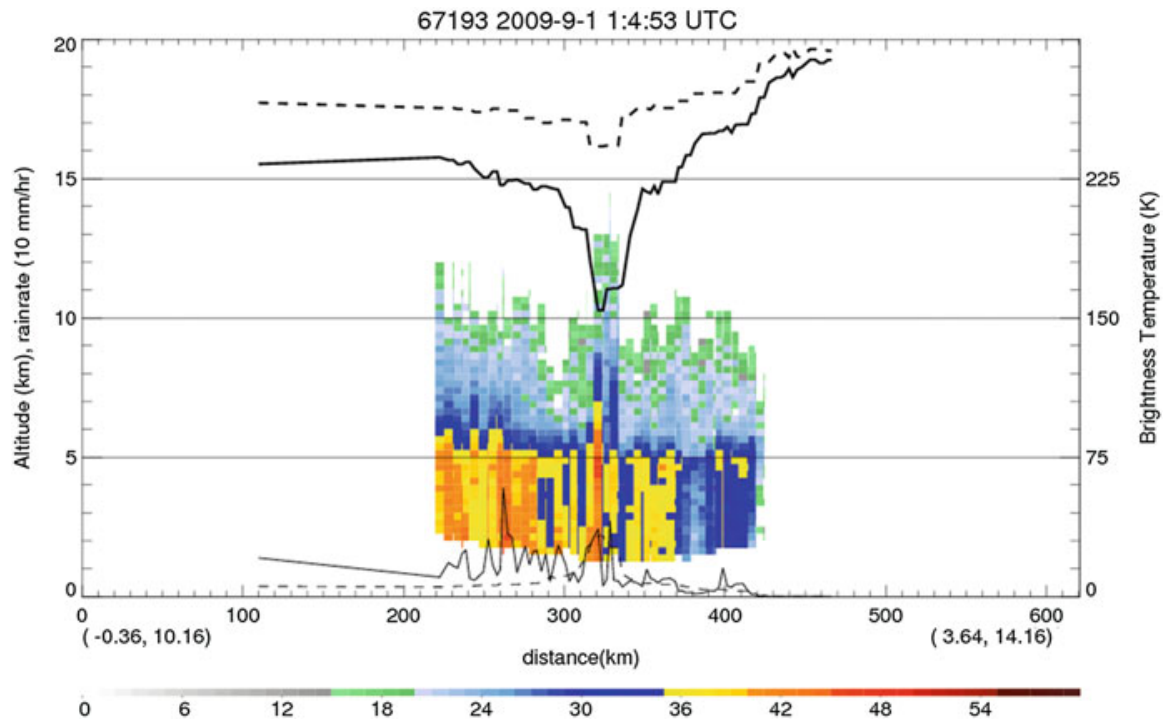

Fig. 2 Vertical cross section of the MCS which occurred on September 1, 2009

The thermodynamic parameters considered in this chapter to discuss the environment of this system are moisture flux convergence at the $1000 \mathrm{mb}$ (hpa) level, lifted index, wind shear between 1 and $3 \mathrm{~km}$, and the skewt diagram (which will provide information on the Lifting Condensation Level (LCL), Level of Free Convection (LFC), Cloud Base (CB), Cloud Top (CT), among others). The environment of the system was investigated a day before the system was captured, the day the system was captured, and the day after the system was captured.

On the August 31, 2009, a day before the flood, the location where this system occurred clearly indicated weak moisture divergence (tendency of a clear sky), in the range of $0-10 \mathrm{~kg} \mathrm{~m}^{-2} \mathrm{~s}^{-1}$ occurring in the zone, but south of this zone is the presence of strong moisture convergence (mechanism by which air is lifted for cloud formation) in the range of $55-80 \mathrm{~kg} \mathrm{~m}^{-2} \mathrm{~s}^{-1}$. A close observation of the time periods indicates that the moisture convergence seem to be migrating northward toward the location of the system. At 18Z, part of the location of the system is already experiencing weak moisture convergence. During the night time of September 1, 2009 , there was a stronger moisture convergence south of the flood event zone, but the moisture convergence was still weak in the flood event zone. Other periods $(6 \mathrm{Z}$, $12 \mathrm{Z}$, and 18Z) did not show strong moisture convergence on the 1st of September 2009 , which was the day of the flood. On 2nd of September 2009, the entire 
environment in which the flood occurred encountered moisture divergence, which indicated that the environment is already dry or in clear sky condition. From the analysis of the moisture flux convergence in the location of the flood, there is tendency that the system developed south of the location, and migrated northward into the zone.

The lifted index (LI), similar to the Convective Available Potential Energy (CAPE), is used to assess low level parcel (in)stability of the troposphere. A negative lifted index (LI) indicates that the boundary layer is unstable with respect to the middle troposphere. Such is an environment in which convection can occur. The more negative the LI, the more unstable the troposphere and the more buoyant the acceleration will be for rising parcels of air from the Planetary Boundary Layer (PBL). On the 31st of August 2009, the environment experienced weak instability during the night, morning, and day time, whereas during the evening time, the environment became more unstable. On the 1st of September 2009, the night time, which was preceded by the evening period of 31st August 2009, showed that the environment of the flood event location was more stable (lesser instability) than the preceding evening. A day after the flood scenario, the stability of the environment was similar to the previous day. From these discussions so far on (in)stability in the environment of the flood scenario using lifted index, it was obvious that the environment was not strongly unstable during the flood scenario event of 1 st September 2009. The only case where large instability was observed, in the range of -4 to $-5 \mathrm{~K}$, was during the evening period which preceded the night time when the flood scenario occurred. In all the other periods, only marginal instabilities were observed, which may not be strong enough for buoyant acceleration of air parcels in the Planetary Boundary Layer (PBL).

The question from the foregoing is can deep convective clouds develop under this kind of environment in which the moisture convergence and instabilities were relatively weak? The zone where the flood event occurred was in the Sudano and it occurred during the JJAS season, which is the season for strong convective storms in the zone.

Vertical wind shear is an important factor for determining the development of Mesoscale Convective Systems (MCSs, Chen et al. 2015). Many studies have examined the effects of vertical wind shear on intensity and organization of convective systems, especially for squall lines (Rotunno et al. 1988; Weisman and Rotunno 2004; Coniglio et al. 2006; Takemi 2006), similar to the event being examined in this section. The effects of strong wind shear on cloud system organization depend on the altitudes where the strong wind shear occurs. Lower level shear is also favorable for organizing systems into lines or quasi-lines (Wu and Yanai 1994; Robe and Emanuel 2001; Richardson et al. 2007; DeLonge et al. 2010), as a reminder that the TRMM snapshot earlier presented showed this particular system to be an organized MCS (squall line). The vertical low level $(1-3 \mathrm{~km})$ wind shear seemed to gradually developed into a severe $\left(>8 \mathrm{~s}^{-1}\right)$ scale wind shear, from the night (0Z) of August 31, 2009 through to the evening period (18Z) of 31st August 2009, in the location of the flood event. This strong (severe) low level vertical wind shear, which is most severe in the eastern axis of the flood location, extends into the flood location during 
the evening period of 31st August 2009 and night time (0Z) of 1st September 2009 (which was the exact time the MCS was captured). This severe low level vertical wind shear could have initiated the development and evolution of convective cloud, and hence MCS similar to the finding that lower level shear directly influences the initiation and evolution of convective clouds due to interactions between lower tropospheric shear and cold pool dynamics (Rotunno et al. 1988; Moncrieff 1992; $\mathrm{Xu}$ et al. 1992), which could have originated from the $1000 \mathrm{mb}$ moisture convergence located southward and migrated northward into the location of the flood event. Historical studies (Simpson 1969; Charba 1974) have shown that a region/zone dominated by evaporatively cooled air which was transported to lower levels via convective downdrafts and thereafter, upon reaching the surface, spread out in the form of a density current is referred to as a convective cold pool region. Goff (1976) stated that cold pools often displaced warmer environmental air as they spread out to adjacent zones. This displaced ambient air is often buoyant and are then uplifted, and thus results in the development or initiation of new convective clouds (Goff 1976; Warner et al. 1980). Droegemeier and Wilhelmson (1985) had noted that two or more collisions of cold pools are effective trigger mechanism for initiation of convection. In addition, Tompkins (2001) and Langhans and Romps (2015) stated in their works that cold pools often bring surface gusty winds that intensify sensible and latent heat fluxes, and thus modifying the thermodynamic characteristics and moisture structure of the boundary layer. The vertical wind shear subsides slightly, although still in the severe category, but maintained the severe category up till the night time (0Z) of the next day (September 2, 2009). Thereafter, the low level wind shear dropped to moderate category on the morning (6Z) of September 2, 2009 and other periods (12Z and 18Z) of the same day.

By the interaction between low level wind shear and cool pools in convective cloud initiation and development (or evolution), especially in the roles these parameters play in the Burkina Faso flood event of 1st September 2009, the next assessment of the case study is to investigate the cloud structure through the use of skew- $t$ diagram.

Results showed that the Convective Available Potential Energy (CAPE) environment was positive $(+)$ for all the periods $(0 \mathrm{Z}, 6 \mathrm{Z}, 12 \mathrm{Z}$, and $18 \mathrm{Z})$ on the 31 st August 2009 , with the peak mean CAPE value $(1392.42 \mathrm{~J} / \mathrm{kg})$ indicated by the evening period (18Z), which was the period that preceded the night time (0Z) of 1st September 2009 when the MCS system was captured. During the night time (0Z) when the MCS system was captured, the top of the cloud is around $13-14 \mathrm{~km}$ similar to the height estimated by the TRMM satellite in the cross section plot discussed earlier. The mean CAPE value dropped significantly during the morning (6Z), day (12Z), and evening (18Z) periods of the same day and through all the periods (0Z, $6 Z, 12 Z$, and 18Z) of the second day, which was September 2, 2009.

Records from the flood, which lasted in the memory of the inhabitant, has it that 180, 386 victims were affected, 62 victims were wound, 41 died, and 33,172 homes were destroyed (Schlef 2018).

The 2009 flood created a lasting and strongly negative impression on the victims; they described the flood as "catastrophic" and "big" and one public official called 
floods "bitter experiences" while a flood victim said "what we lived through, we have no desire to experience again" (Schlef 2018). The flood victims and some public officials also shared their personal stories, revealing the unquantifiable and sometimes long-lasting effects of experiencing a devastating flood: "We left the house ... it overflowed ... I didn't know how to swim, so they dragged me along ... even now when it rains at night I can't sleep - I'm afraid! And I'm not the only one" (Schlef 2018).

\section{The 2012 Flood in Nigeria}

Between July and October 2012, floods which resulted from the predicted heavy rains and the released water from Lagdo dam in Cameroon pushed rivers over their banks and submerged hundreds of thousands of acres of farmland. By mid-October, these floods had forced 1.3 million people from their homes and claimed 431 lives (Agada 2015). The severity of the 2012 Nigeria flood made it a focal point of this chapter. The TRMM snapshot of a Mesoscale Convective System (MCS), with an extreme volume rainfall (Table 2) of 351,310.9 $\left((\mathrm{mm} / \mathrm{h}) * \mathrm{~km}^{2}\right)$ on 29th September 2012 (one of the days of the flood), in Ofutop II (a community close to Ikom Cross River state) is shown in Fig. 3. The Visible Infrared Scanner (VIRS), in the TRMM satellite, estimated the brightness temperature as low as $186 \mathrm{~K}$ in Fig. 3a. The rain rate from the single system is over $140 \mathrm{~mm} / \mathrm{h}$ and the MCS is only $34.1 \%$ convective (Table 2), meaning that the trailing stratiform portion (region) within the system is $65.9 \%$. The total number of flash count from the single system is 5 (Table 2) as estimated by the Lightning Imaging Sensor (LIS) of the TRMM satellite. The system was captured at exactly 7:38:20 am on the 29th of September 2012 by the TRMM satellite. By the last three (3) sentences (stratiform region was $65.9 \%$, only 5 flashcount was estimated, and the system occurred in the morning diurnal), clearly this system is more of stratiform than convective, which would have lasted for a long time before it completely decayed. The vertical cross section in Fig. 4 shows that the system extends over $200 \mathrm{~km}$ horizontally and reached only about $8 \mathrm{~km}$ altitude in the atmosphere, and no depressed brightness temperature was observed in the cross section of the system.

As was analyzed for the Burkina Faso flood scenario, the thermodynamic parameters to investigate the environment of this system are: moisture flux convergence at the $1000 \mathrm{mb}$ (hpa) level, lifted index, wind shear between 1 and $3 \mathrm{~km}$, and the skewt diagram (which will provide information on the Lifting Condensation Level (LCL), Level of Free Convection (LFC), Cloud Base (CB), Cloud Top (CT), among others). For this case study, the environment of the system was investigated a day before the

Table 2 Summary of some parameters from the observed system during 29th September 2012

\begin{tabular}{l|l|l|l|l|l}
\hline Latitude & Longitude & \% convective & Size $\left(\mathrm{km}^{2}\right)$ & Volrain $\left((\mathrm{mm} / \mathrm{h}) * \mathrm{~km}^{2}\right)$ & $\begin{array}{l}\text { Flashcount } \\
(\#)\end{array}$ \\
\hline 6.78 & 7.13 & 34.1 & 83190.8 & 351310.9 & 5 \\
\hline
\end{tabular}



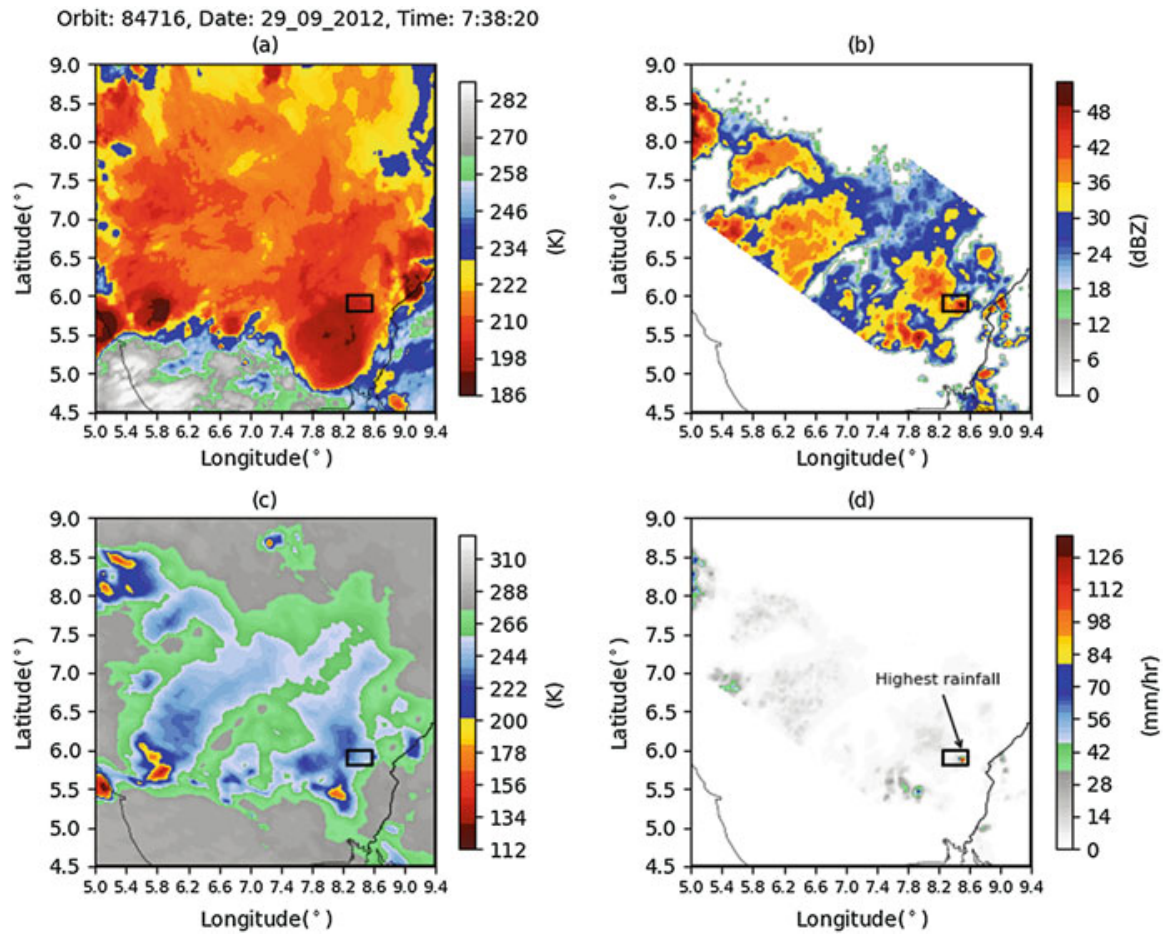

Fig. 3 Case study of TRMM-observed MCS which occurred on September 29, 2012 in Nigeria, where (a) Infrared (10.8 micron) brightness temperature (Tb), (b) PR near surface reflectivity, (c) $85 \mathrm{GHz} \mathrm{PCT}$ of MCS, and (d) $2 \mathrm{~A} 25$ near surface rain rate

system was captured, the day the system was captured, and five (5) additional days after the system was captured because the flood affected many parts of Nigeria, and was reported to last many days beginning from around July to around mid-October.

On 28th of September 2012, a day before the system was captured by the TRMM satellite, extreme low level moisture flux convergence was observed during all the periods (0Z, 6Z, 12Z and 18Z), especially along the axis of the river Benue bank, which were the most affected areas (the Nigeria savannah zone). The communities in Nigeria affected by this extreme low level moisture flux convergence are Aguleri in Anambra state, Katsina Ala in Benue state, Makurdi in Benue state, Ikom in Cross River state, Lokoja in Kogi state, among others. It has been noted by Ismail and Siadari (2017) that if the atmosphere is unstable with abundant low-level moisture and a mechanism exists to lift the air (thereby releasing the potential instability), convective weather and rainfall (showers) can develop. On September 29, 2012, the affected areas were still under the influenced of extreme low-level moisture flux convergence, including Ofutop II in Cross River state where the peak rainfall rate was observed. On September 30, 2012, Aguleri community in Anambra state was under the influence of extreme low level moisture flux convergence during the night time. According to Vanguard newspaper of 7th October 2012, the then governor of 


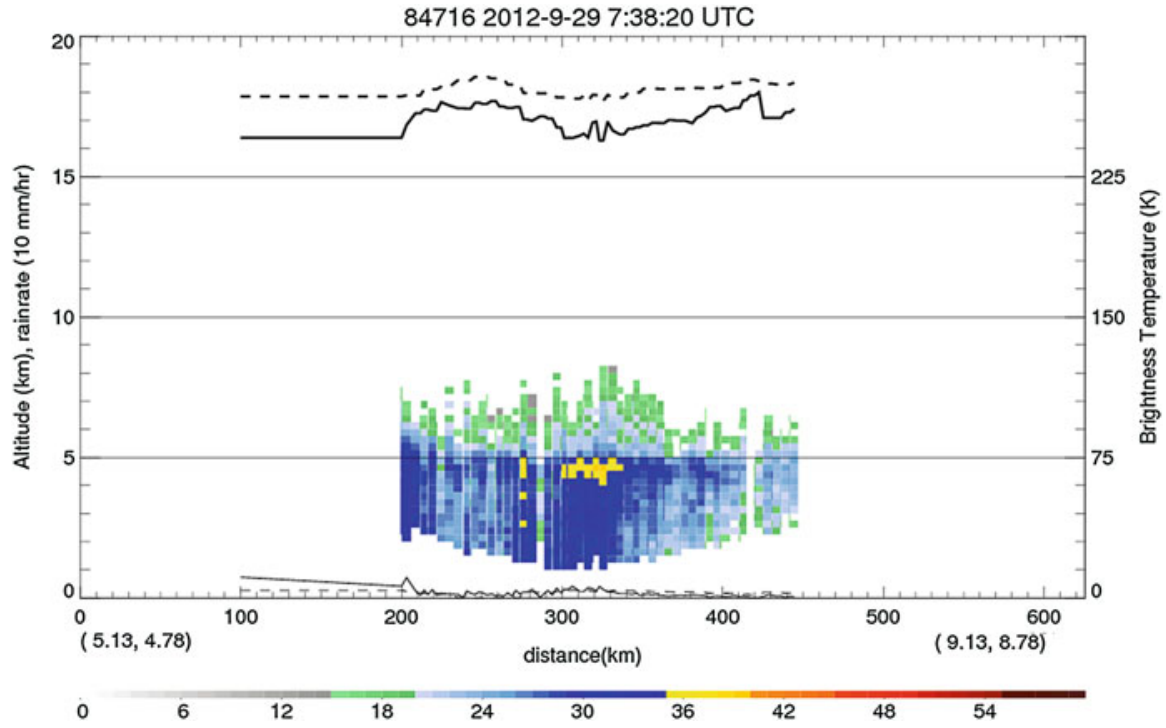

Fig. 4 Vertical cross section of the MCS which occurred on September 29, 2012

Anambra state, Governor Peter Obi, had to suspend the Independence Day celebration of Nigeria, slated for 1 st of October 2012, so as to pass through the flooded Onitsha-Osomala road in Nmiata and Ogbaru road in Anambra West in other to supervise the removal of victims trapped in their communities by the devastating flood event. Vanguard newspaper of 7th October 2012 further stated that the entire Nzam, Aguleri Otu (a community where the then President of Nigeria, Goodluck Jonathan, commissioned the Orient Petroleum facility), Nmiata, Odekpe, Osomala, Osuche, Atani, Amii, Umuzu, and other communities in Anambra state were under water. Properties that worth billions of naira in the four local government areas of Anambra state, where these communities were situated, were destroyed by the flood. According to the Vanguard of 7 th October 2012, the governor was able to persuade the people to leave their properties and secure their lives. He, the then Governor Peter Obi, thereafter used canoe to visit other communities trapped across the River Niger basin of Anambra state. By the time the then governor Peter Obi returned to his entourage to continue his inspection of other affected communities, flood had already filled the whole road through which he would leave. The governor and his entourage had to walk through the flood (Fig. 5a), which leveled-up to their waists, in other to reach the convoy of vehicles. On 1st through to 4th October 2012, all the communities along the River Benue axis were still under the influence of extreme low level moisture flux convergence. This implied that the communities would have experienced continuous heavy precipitation during these periods, apart from the water that was released from the lagdo dam (see Fig. 6) in Cameroon.

It was also reported (Vanguard, October 7, 2012), that about 79, 000 people were displaced in Cross River State. Out of the number, more than half - 49, 918 - were 

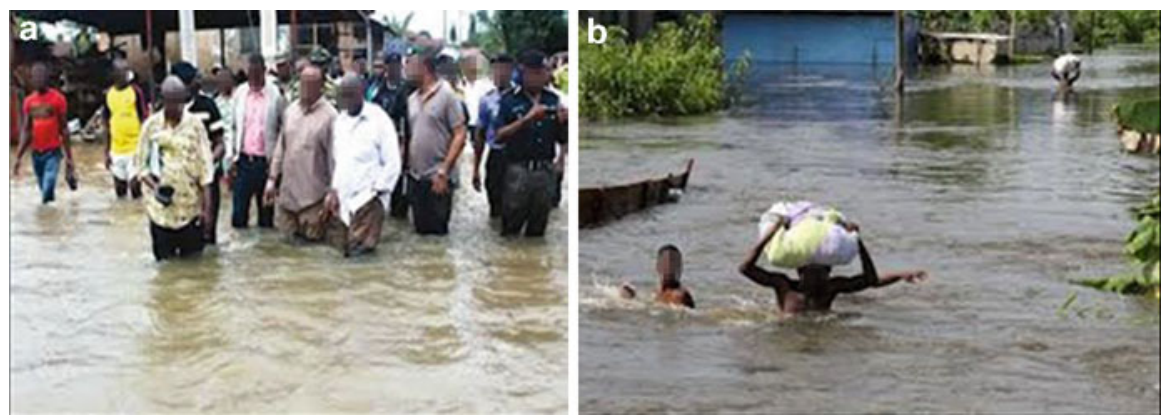

Fig. 5 Situations during the 2012 flood in Anambra state (a and b). (Source: Emmanuel et al. 2015)

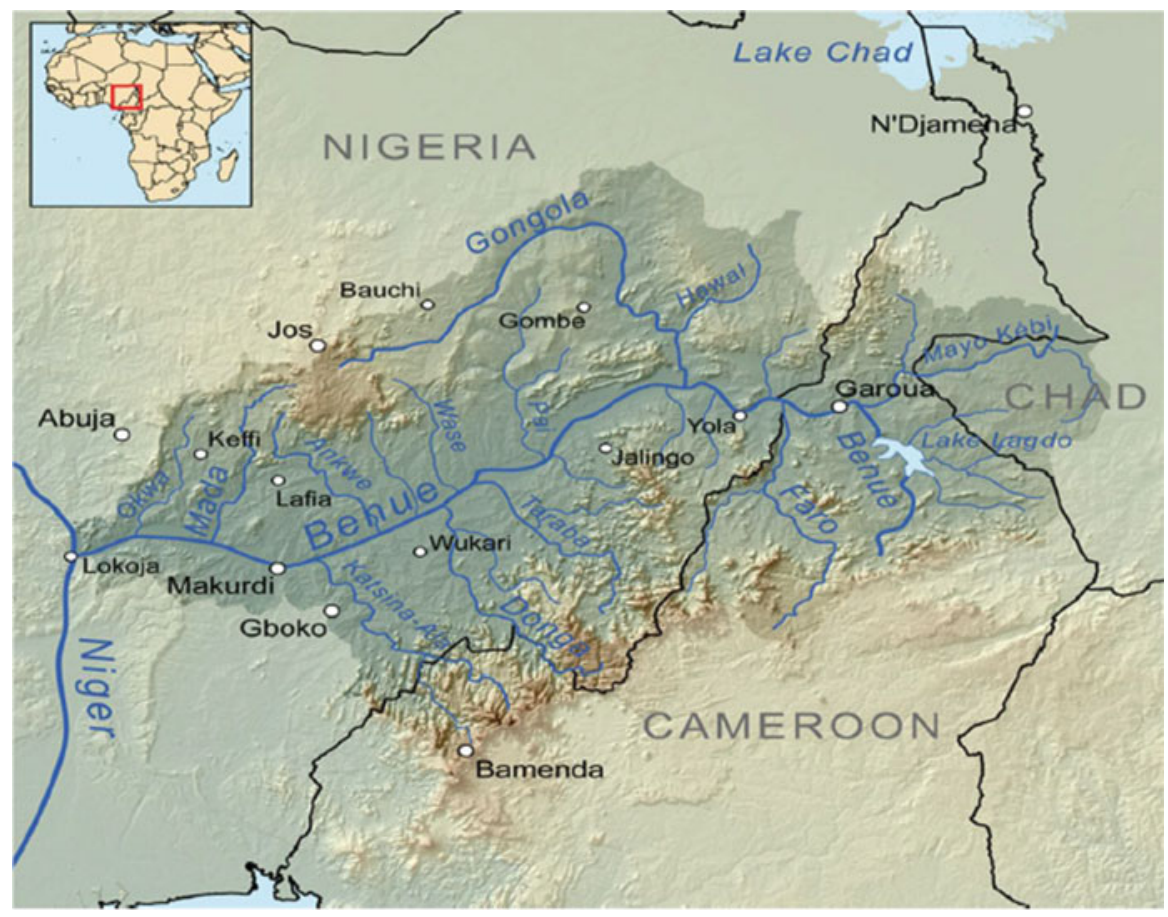

Fig. 6 Map showing Nigeria, Cameroon, Benue River, and Lake Lagdo in Cameroon (http://en. wikipedia.org/wiki/). (Source: Agada (2015))

displaced by flood as a result of the release of water from Lagdo Dam in Cameroon. In Ikom Local Government Area, close to the community where the peak rainfall was observed on 29th September 2012, the flood also displaced 26 communities and destroyed one school and two markets. 
The stability of the environment, on 28th September 2012 indicated that the entire zone under investigation was extremely unstable, particularly during the evening time (18Z) of the day that preceded the MCS event that was captured by TRMM satellite. It clearly showed that the Ofutop II community in Cross River was extremely unstable during the evening period of 28th September 2012 and during the night (0Z) of September 29, 2012 (the day the MCS was captured by TRMM satellite). During the morning time (6Z), the instability of the environment in Ofutop II of Cross River state had subsided to moderate category, but increased again to severe category during the day (12Z) and evening (18Z) periods. On September 30, 2012, the day that preceded the governor's visit to communities, Aguleri in Anambra state was under extreme instability during the evening period (18Z). Places like Makurdi and Katsina Ala in Benue state were also under extreme instability during the same evening diurnal. On 1st through to 4th October 2012, most communities in the affected zone were under moderate to extreme instability as indicated by the lifted index, particularly during the night (0Z), day (12Z) and evening (18Z) periods. The morning diurnals showed weaker instabilities in most cases during these periods (1st - 4th October, 2012).

On the 28th of September 2012, there was severe - extreme - wind shear in the environment of the event, which cut across the seven communities under investigation in this work. The most extreme wind shear was observed in Lokoja of Kogi state during the evening period (18Z) of 28th September 2012, which was earlier observed during the night period (6Z) of the same day. Lokoja was under the influence of extreme low level vertical wind the second day, 29th September 2012 during the night $(0 \mathrm{Z})$ and evening (18Z) periods. Because the entire Nigeria savannah environment was under the influence of strong moisture convergence during this period, hence the presence of cool pool dynamics in combination with the extreme low level vertical wind shear, among other factors would definitely had initiated deep convective systems, particularly in Lokoja and surrounding Benue state. Ofutop II and surrounding Ikom, in Cross River state, were particularly under the influence of severe low level vertical wind shear on the 28th September 2012 in all the periods. On 29th and 30th September 2012, the low level vertical wind shear in Ofutop II was already suppressed. It was noted that Lokoja in Kogi state and Makurdi in Benue state were still under the influence of extreme low level vertical wind shear on 30th September 2012. On 1st of October 2012, all the Nigeria savannah communities under investigation were influenced by extreme low level vertical wind shear. This convective environment remained under the influence of extreme low level vertical wind shear during 2nd, 3rd, and 4th of October 2012. Agada (2015) stated that the two most affected areas were Kogi and Benue States.

Results for the Ofutop II community where the peak rainfall rate was captured by the TRMM satellite showed that the Convective Available Potential Energy (CAPE) environment was positive $(+)$ for the night time (0Z) on the 28th September 2012, with the peak mean CAPE value $(4672.80 \mathrm{~J} / \mathrm{kg}$ ) and highest cloud top (slightly above $15 \mathrm{~km}$ ) indicated by the evening time (18Z). During the night time (0Z) of 29th September 2012, which was the diurnal that preceded the morning time (0Z) of 29th September 2012 when the MCS system was captured, the top of the cloud as 


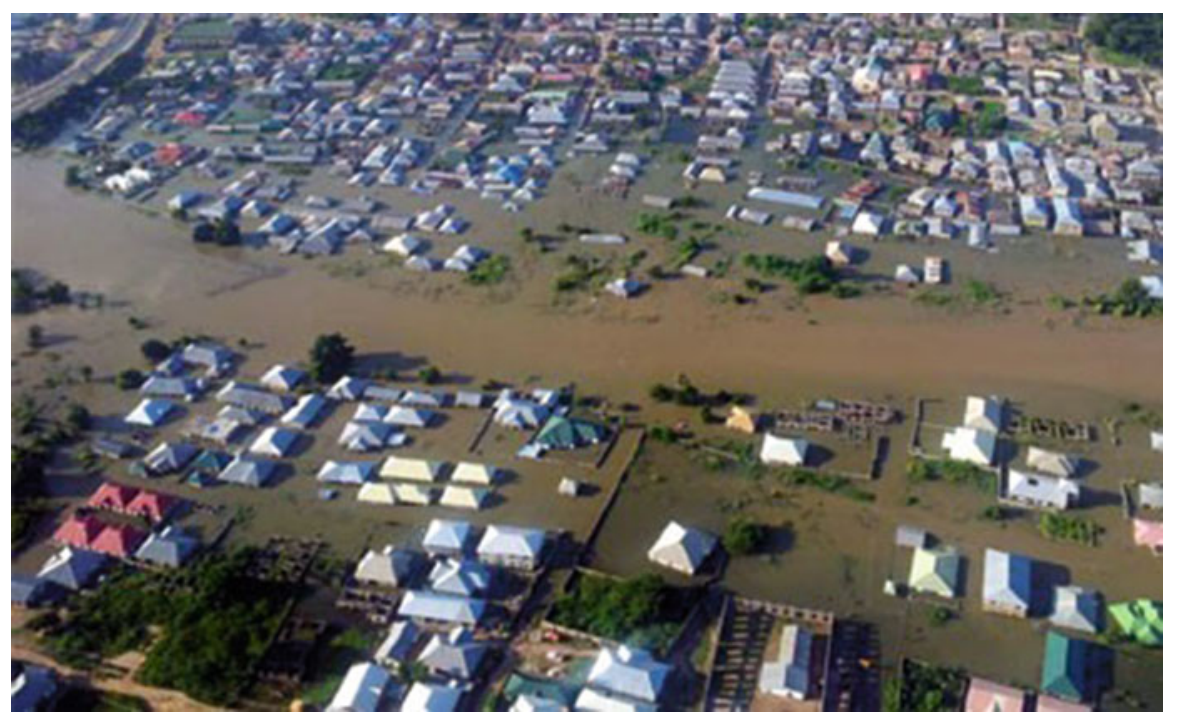

Fig. 7 Areal view of Lokoja, Kogi State, under the siege of flood. (Source: Vanguard 2012)

shown by the skew-t diagram was around 14-15 km, quite different from the height estimated by the TRMM satellite in the cross section plot, because the location (Ofutop II in Cross River state) under investigation is different from the nadir latitude-longitude of observation by the TRMM satellite. The mean CAPE value dropped significantly during the morning (6Z), day (12Z), and evening (18Z) periods of the same day but increased during the day (12Z) and evening (18Z) periods (12Z and 18Z) of the second day, which was 30th September 2012.

According to Vanguard (2012), horror came in the shape of suicide in one of the resettlement camps in Kogi State where two victims of the ravaging floods decided to take their own lives. They could not bear the loss of properties (Vanguard 2012). In relief camps in Kogi, 20 people have already died. The conditions were worst, two bags of rice for 2000 victims per day: How would it go round? The flood ravaged Lokoja (Vanguard 2012) as shown in Fig. 7 above.

\section{Conclusions}

A combination of TRMM observed convective properties and reanalysis dataset have provided valuable information for analyzing flood scenarios in West Africa and have proved reliable based on the results generated from this research work.

At the time of written this chapter, flood disasters has become a yearly occurrence in all the locations affected by the 2012 Nigerian flood. There is no specific climate change adaptation strategies adopted in any of these locations. The inhabitants watched their properties and farmlands destroyed every year. There cry had always been to the government, but in all, relief materials are what they get in return. 
Because this climate change hazard has become an annual occurrence in some parts of Nigeria and West Africa in general, this work therefore suggest that governments in affected countries put in place mitigation strategies to reduce the impact of future occurrence.

Acknowledgement This research was supported by Tertiary Education Trust Fund (TETFund) grant of the Nigerian government under the academic staff development program of the Federal University of Technology Akure for a split-site research program with the Texas A \& M University Corpus Christi United States. Special thanks to Dr. Chuntao Liu, who granted me access to the Precipitation Feature database at Texas A \& M University Corpus Christi United States.

\section{References}

Agada S (2015) A serious flooding event in Nigeria in 2012 with specific focus on Benue State: a brief review. Nat Hazards 77:1405-1414. https://doi.org/10.1007/s11069-015-1639-4

Akaeze A (2012) An avoidable disaster. Tell special report, October 8, 2012.

Balogun RA, Liu C, Debo AZ, Okogbue EC, Adesanya AE (2018) Intraseasonal and seasonal variability of convective properties of monsoon precipitation systems over West and Central Africa. Theor Appl Climatol. https://doi.org/10.1007/s00704-018-2692-1

Charba J (1974) Application of gravity current model to analysis of squall-line gust front. Mon Weather Rev 102(2):140-156

Chen Q, Fan J, Hagos S, Gustafson WI Jr, Berg LK (2015) Roles of wind shear at different vertical levels: cloud system organization and properties. J Geophys Res Atmos 120:65516574. https://doi.org/10.1002/2015JD023253

Coniglio MC, Stensrud DJ, Wicker LJ (2006) Effects of upper-level shear on the structure and maintenance of strong quasi-linear mesoscale convective systems. J Atmos Sci 63(4):12311252. https://doi.org/10.1175/jas3681.1

Dee DP et al (2011) The ERA-Interim reanalysis: configuration and performance of the data assimilation system. Q J Roy Meteor Soc 137:553-597

DeLonge MS, Fuentes JD, Chan S, Kucera PA, Joseph E, Gaye AT, Daouda B (2010) Attributes of mesoscale convective systems at the land-ocean transition in Senegal during NASA African monsoon multidisciplinary analyses 2006. J Geophys Res 115:D10213. https://oi.org/10.1029/ 2009JD012518

Droegemeier KK, Wilhelmson RB (1985) Three-dimensional numerical modeling of convection produced by interacting thunderstorm outflows. Part I: control simulation and low-level moisture variations. J Atmos Sci 42(22):2381-2403. https://doi.org/10.1175/1520-0469(1985) 042<2381:TDNMOC $>2.0 . \mathrm{CO} ; 2$

Emmanuel Udo A, Ojinnaka OC, Baywood CN, Gift UA (2015) Flood hazard analysis and damage assessment of 2012 flood in Anambra state using GIS and remote sensing approach. Am J Geogr Inform Syst 4(1):38-51. https://doi.org/10.5923/j.ajgis.20150401.03

Galvin JFP (2010) Two easterly waves in West Africa in summer 2009. Weather 65(8):219-227. https://doi.org/10.1002/wea.605.

GBF, WB, UN (2010) Inondations du 1er Septembre 2009 au Burkina Faso: evaluation des dommages, pertes et besoins de construction, de reconstruction et de relevement (Vol. 56803 BF). Government of Burkina Faso, World Bank, United Nations

Goff RC (1976) Vertical structure of thunderstorm outflows. Mon Weather Rev 104(11):1429 1440. https://doi.org/10.1175/1520-0493(1976)104<1429:VSOTO > 2.0.CO;2

Ismail P, Siadari EL (2017) Atmospheric conditions analysis of the heavy rain phenomenon in Biak (case study 4-5 December 2014). J Phys Conf Ser 795:012015 
Karambiri H (2009) Breve analyse frequentielle de la pluie du 1er septembre 2009 a Ouagadougou (Burkina Faso). Ouagadougou: 2iE.

Langhans W, Romps DM (2015) The origin of water vapor rings in tropical oceanic cold pools. Geophys Res Lett 42:7825-7834. https://doi.org/10.1002/2015GL065623

Magami I, Yahaya S, Mohammed K (2014) Causes and consequences of flooding in Nigeria: a review. Biol Environ Sci J Tropics 11(2):154-162

Merem E, Twumasi Y, Wesley J, Alsarari M, Fageir S, Crisler M, Romorno C, Olagbegi D, Hines A, Ochai G, Nwagboso E, Leggett S, Foster D, Purry V, Washington J (2019) Regional assessment of climate change hazards in Southern Nigeria with GIS. J Saf Eng 8(1):9-27

Moncrieff MW (1992) Organized convective systems: archetypal dynamical models, mass and momentumflux theory, and parametrization. Q J R Meteorol Soc 118(507):819-850. https://doi. org/10.1002/qj.49711850703

NIMET (2012) Seasonal rainfall prediction and socio-economic implications for Nigeria, Nigerian meteorological agency. http://nimet.gov.ng/sites/default/files/publications/2012-seasonal-rain fall prediction.pdf

Njoku J (2013) 2012 year of flood fury: a disaster foretold, but ignored? Vanguardngrnews, Saturday August 17, 2013.

Ojobor L (2014) The 2012 flood disaster in Nigeria: impact on the operations of small scale business women in Igboland. Int J Bus Manag Stud 3(1):463-481

Post-Disaster Needs Assessment 2012 Floods (2013) A report by the Federal Government of Nigeria with technical support from the World Bank, EU, UN, and Other Partners

Richardson YP, Droegemeier KK, Davies-Jones RP (2007) The influence of horizontal environmental variability on numerically simulated convective storms. Part I: variations in vertical shear. Mon Weather Rev 135(10):3429-3455. https://doi.org/10.1175/mwr3463.1

Robe FR, Emanuel KA (2001) The effect of vertical wind shear on radiative-convective equilibrium states. J Atmos Sci 58(11):1427-1445. https://doi.org/10.1175/1520-0469(2001) $058<1427$ :teovws $>2.0$. co; 2

Rotunno R, Klemp JB, Weisman ML (1988) A theory for strong, long-lived squall lines. J Atmos Sci 45(3):463-485. https://doi.org/10.1175/15200469(1988)045<0463:atfsll >2.0.co;2

Schlef K (2018) Flood risk assessment, management and perceptions in a changing world. Doctoral dissertations. 1273. https://scholarworks.umass.edu/dissertations_2/1273

Simmons A, Uppala S, Dee D, Kobayashi S (2007) ERA-interim: new ECMWF reanalysis products from 1989 onwards. ECMWF News1 110:25-35

Simpson JE (1969) A comparison between laboratory and atmospheric density currents. Q J R Meteorol Soc 95(406):758-765. https://doi.org/10.1002/qj.49709540609

Takemi T (2006) Impacts of moisture profile on the evolution and organization of midlatitude squall lines under various shear conditions. Atmos Res 82(1-2):37-54. https://doi.org/10.1016/j. atmosres.2005.01.007

Tompkins AM (2001) Organization of tropical convection in low vertical wind shears: the role of cold pools. J Atmos Sci 58(13):1650-1672. https://doi.org/10.1175/15200469(2001) $058<1650$ :OOTCIL $>2.0 . \mathrm{CO} ; 2$

Vangard Newspaper (2012) Rage of nature: flood ravages communities across Nigeria. 7th October 2012

Warner C, Simpson J, Van Helvoirt G, Martin DW, Suchman D, Austin GL (1980) Deep convection on day 261 of GATE. Mon Weather Rev 108(2):169-194. https://doi.org/10.1175/1520-0493 (1980) $108<0169$ :DCODOG $>2.0$. CO; 2

WB (2017) Burkina Faso overview. Retrieved January 1, 2017, from http://www.worldbank.org/en/ country/burkinafaso/overview

Weisman ML, Rotunno R (2004) “A theory for strong long-lived squall lines” revisited. J Atmos Sci 61(4):361-382. https://doi.org/10.1175/15200469(2004)061<0361:atfsls > 2.0.co;2 
Wu X, Yanai M (1994) Effects of vertical wind shear on the cumulus transport of momentum: observations and parameterization. J Atmos Sci 51(12):1640-1660. https://doi.org/10.1175/ 1520-0469(1994)051<1640:eovwso $>2.0 . c 0 ; 2$

Xu K-M, Arakawa A, Krueger SK (1992) The macroscopic behavior of cumulus ensembles simulated by a cumulus ensemble model. J Atmos Sci 49(24):2402-2420. https://doi.org/ 10.1175/1520-0469(1992)049<2402:tmboce $>2.0$. co;2

Open Access This chapter is licensed under the terms of the Creative Commons Attribution 4.0 International License (http://creativecommons.org/licenses/by/4.0/), which permits use, sharing, adaptation, distribution and reproduction in any medium or format, as long as you give appropriate credit to the original author(s) and the source, provide a link to the Creative Commons license and indicate if changes were made.

The images or other third party material in this chapter are included in the chapter's Creative Commons license, unless indicated otherwise in a credit line to the material. If material is not included in the chapter's Creative Commons license and your intended use is not permitted by statutory regulation or exceeds the permitted use, you will need to obtain permission directly from the copyright holder.

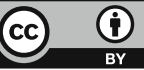

